$<$ 原 著 $>$

兵庫県南部加古川流域における1990年の A 型肝炎の流行に関する調査

\begin{tabular}{|c|c|c|c|c|c|}
\hline 早川みち子11 & 上野 & 幹彦"1) & 福本 & 廣文 ${ }^{2)}$ & 後藤 武男 ${ }^{3)}$ \\
\hline 清水 伸一4) & 天野 & 昌彦5) & 鎮西 & 忠信6) & \\
\hline
\end{tabular}

要 旨：1989年12月より1990年 7 月にかけて兵庫県南部加古川流域の東播地域において A 型 肝炎の流行を経験し，多施設共同による調査を怙こなった．対象となった A 型肝炎患者215人 （男性116人，女性99人）の年齢平均値は 32.7 歳で，2歳から79歳にわたる年齢分布を示し， 30 歳台が54人で最も多かった. 60 藏以上の高齢者は 9 人で, 全体の $4.3 \%$ あっむた. 発症時期は 3 月上旬と 5 月上旬の 2 つのピークが認められ，二峰性の形をしめした．家族内発症は 12 家族, 30 人であり，このうち 8 家族，18人が同時発症であった．検查值では血清 GOT, GPT, 総ビリ ルビン值の各患者の頂值の平均値はそれぞれ $1,417 \mathrm{IU} / \mathrm{L}(41 \sim 7,590), 1,835 \mathrm{IU} / \mathrm{L}(40 \sim 7,060)$,

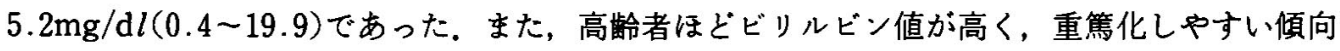
にあると考えられた。

索引用語： $\mathrm{A}$ 型肝炎 流行疫学

\section{緒 言}

A 型肝炎は日本の衛生環境の整備に伴いその発生 数が減少し，抗体保持者は減少してきている．特に若 年者にその傾向が認められる1. そのため逆説的に集 中的な流行が起こる可能性があり，比較的予後は良好 な疾患とはい充，社会的な影響は大きいといわねばな らない。また，高齢者に打いても近年 A 型肝炎の発症 は多く，その場合は重篤になり，また遷延化する傾向 が報告されている5,6). 我々は1990年に兵庫県南部加古 川流域の東播地域に㧊いて A 型肝炎の流行を経験し たが，上記の点を考虑しアンケート調查に基づく検討 を行ったので報告する.

\section{対象及ひ方法}

加古川流域の主たる中核病院にアンケートを送付 し, 1989年末から1990年に発症した A 型肝炎患者の年 路, 性別, 居住場所, 発症時期, 血清 GOT, GPT, 総 ビリルビン值を調査した。臨床上急性肝炎と認められ, かつ A 型肝炎ウイルス IgM 抗体の陽性の者を対象と した.

共同調査の協力病院は以下の 6 病院である. 国立加 古川病院，神鋼加古川病院，高砂市民病院，市立小野

1)国立加古川病院内科, 2)神鍋加古川病院内科, 3)高砂市 民病院内科，“市立小野病院内科, 51 市立西脇病院内 科, 6)加古川市民病院内科

〈受付日1992年 6 月 22 日 $>$
病院，市立西脇病院，加古川市民病院.

結 果

兵庫県南部の東播地域は加古川流域を中心とし，沿 岸部は工業地域と住宅地域であるが，内陸部は農業地 域である。この地域における人口と一般病院の年間退 院延患者縂数は，兵庫県の統計によるとそれぞれ667， 980 人 (1985年)，35,937人 (1989年)である。アンヶー 卜調査によりとらえられた患者数は，1989年12月下旬 より1990年 7 月上旬に発症した 215 人であった。男性は 116人，女性は99人で男女差はなかった。平均年齢は 32.7 歳で，2歳から79歳にわたる年跉分布を示し，30 荿台が54人で最も多かった。60歳以上の高齢者は 9 人

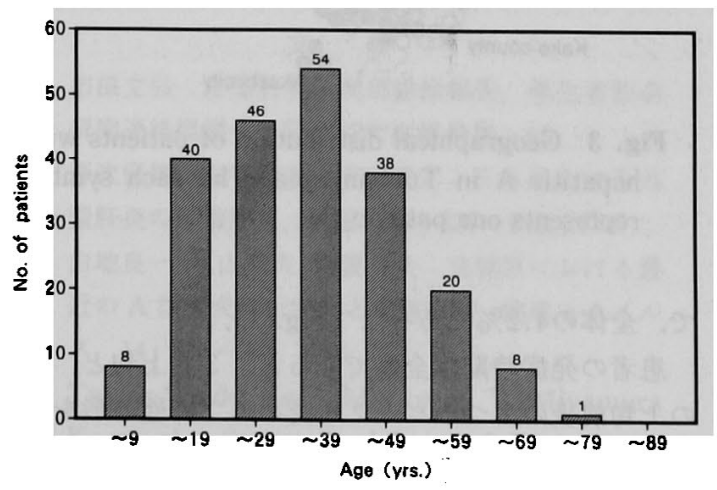

Fig. 1 Age distribution of patients with hepatitis A. 


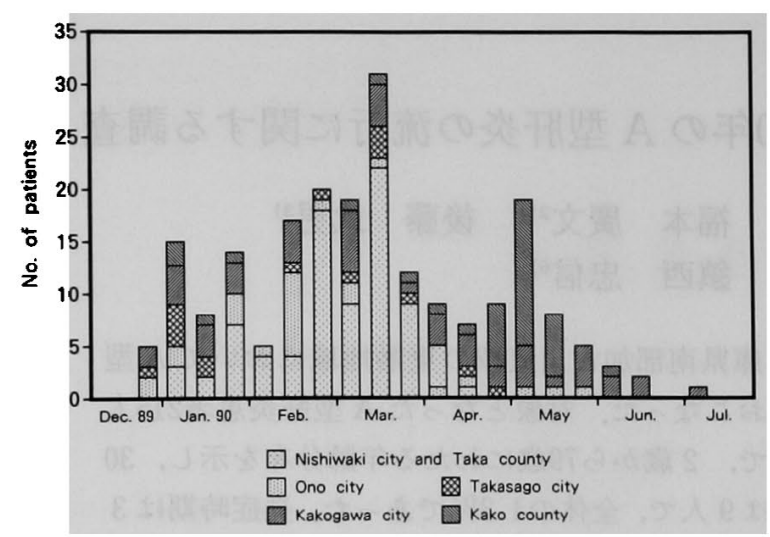

Fig. 2 Incidence of patients from December 1989 to July 1990.

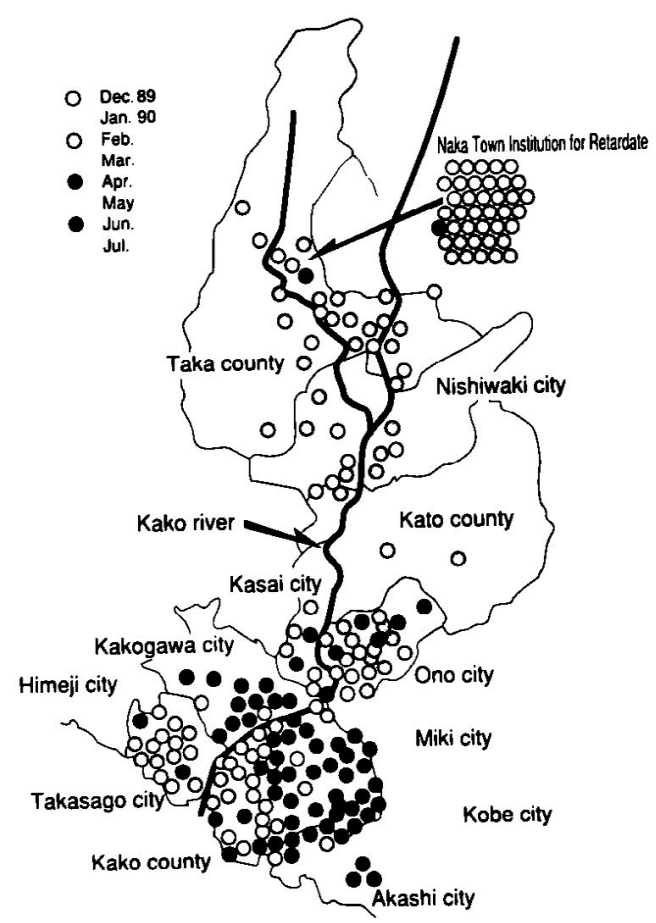

Fig. 3 Geographical distribution of patients with hepatitis A in Touban area. The each symbol represents one patient.

\section{で，全体の4.2\%であった（Fig. 1).}

患者の発症時期は全体でみると， 3 月上旬と， 5 月 の上旬前後の 2 つのピークを認める二峰性の形をしめ した (Fig. 2)。その前半の時期では加古川上流の西脇 市と中町で多くの患者が発生しているが, 後半の時期 では加古川下流の東部の地域, 加古郡で多発している

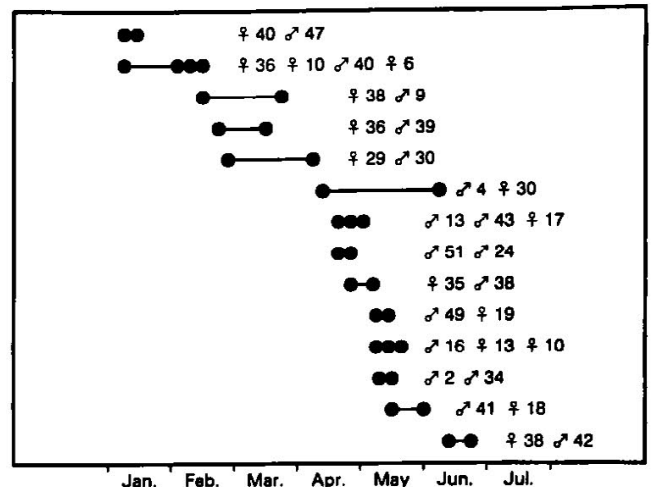

Fig. 4 Familial occurrence of hepatitis A.

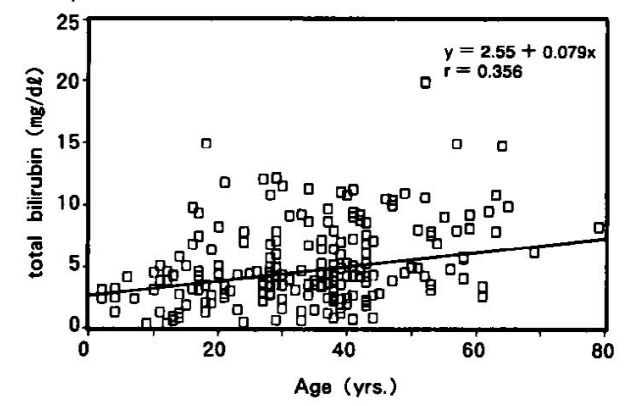

Fig. 5 Correlation between age and peak serum total bilirubin level of patients with hepatitis A.

(Fig. 3). 前半の時期には精神薄弱者の施設内で大量 発生しており，この施設内発症は40人であった。後半 の時期については，原因は不明であるが，加古郡では 26 人が 4 月下旬か 55 月上旬の一時期に集中して発症 していた.

家族内で発症した患者数は，とらえられた限りでは 14家族で32人であった (Fig. 4)。ささらに発症時期の間 隔が 2 週間以内のるのを同時発症と考えると, 上記の 14家族の5ち 9 家族，20人が同時発症したことになり， このらち 8 家族が二峰性のビークの後半の時期に発症 した.

また, 検査值では各患者の頂値は血清 GOT, GPT, 総ビリルビン値の平均值でそれぞれ1,417IU/L $(41 \sim 7,590), 1.835 \mathrm{IU} / \mathrm{L}(40 \sim 7,060), 5.2 \mathrm{mg} / \mathrm{d} l$ (0.4〜19.9) であった. 高値を示す症例が認められた が, 劇症肝炎はなかった。また，腎炎の合併む認めて いない。

年齢と血清トランスフミナーゼ值の間には相関関保 は認められなかったが, 総ビリルビン值の間には $\mathrm{r}=$ 
$0.317 て ゙ \mathrm{t}$ 検定で $\mathrm{p}<0.05$ の有意な正の相関が認めら れた (Fig. 5).

\section{考察}

今回の調查では1989年12月から1990年 7 月まで患者 の発生が認められる。通常 A 型肝炎は 3 月前後の早春 に多発すると言われている”．加古川上流の西脇市と 中町においては1990年のはじめから4月にかけて大量 の A 型肝炎の発症を認めている.この地域では $2 ， 3$ 月に患者数が多く，4月にはすでに発生は減少してい た，このため，管轄の西脇保険所は同年の 5 月に肝炎 流行の終結宣言を行っている8). しかし, 同時期は加古 郡にて大量の患者が発症している時期である，全体で 見ると本文中でも示した様に二峰性の流行があったこ とは明らかである. A 型肝炎の潜伏期は 2 週間ないし 6 週間と比較的長く，患者が発症した時点ではウイル スは既に排泄されていることを考えると，2次感染， 3 次感染の予防はかなり困難であるといえる.

流行の前半の時期では精神薄弱者の施設内で大量の 患者発生が認められ、この施設内発生は40人であった. 施設内での感染は充分考劣られるが，一般地域での患 者数む西脇保健所管内では 40 人発生しているため, 感 染経路を特定することは困難であった。 また，従来か らこのよらな施設内，あるいは学校内での大量発生は

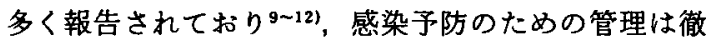
底できない傾向がある。

家族内発生例をみると同一の感染源を示唆する同時 発生か，家族内発生の 3 分の 2 に認められる. しかし， 家族内発生が家族内感染によるとみられる報告もあ

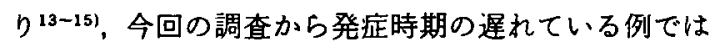
母子間あるいは妻から夫の順で発生しており，食事を 介する家族間の感染の可能性を示唆する。

患者の年齢は従来の報告では20がら30歳台が最も多 い16 19). 今回の我々の経験では，30歳台に年龄のビー クを認めているが, 10歳から40歳台までは患者数には ほとんど差がなく，従来に比してビークは高龄者にシ フトし，しかむ全体に高年需化している.

また，60歳以上の高龄者は 9 人で，4.3\%であった。 50歳以上では29人 (13.5\%) で，いずれも従来の報告 と比ぺて高い頻度で13 16), 最高年龄者は79歳であっ た.

一般健常者の血清中 A 型肝炎抗体は60歳以上では 90\%以上陽性であるとの報告がある1ー4).しかし，これ までの報告は数年以上前のものであり，今回の調査結 果を考えると，今後高齫者の A 型肝炎の発症が増加す
る可能性が示唆される。

神代らは高龄者のA型肝炎では顕性黄疸の時期が 遷延化したり，トランスフミナーゼ異常日数が若年者 と比して延長することを報告している5)。また，村岡は 10年間の A 型肝炎症例の調査から，最近は患者が高龄 化するのにともなって病状む重篤化していると報告し ている6).

我々の今回の経験でも，患者は高龄化しており，総 ビリルビン值は高秢者ほど高い值を示した。 トランス アミナーゼ值は年龃と相関は認められなかったが，こ れはビリルビン値と比べて発症早期にそのピークがあ り，測定の時点ではとらえられなかったためと考えら れ，ビリルビン值が重症の指標となると考えた。高齢 者の重篤化の原因として，兔疫機能の低下，代謝性疾 患などの合併症の増加が考えられている，さらに，肝 機能障害以外にも，発熱と食事摃取低下による脱水拧 よび，全身の栄養状態の悪化にともならストレスも無 視できない要素として重要であろう。

A 型肝炎は慢性化せず，自覚症状は速やかに改善 し, 通常 1 ないし 2 カ月で生化学検査侹は正常化する ため予後良好の疾患と考光られている。しかし，以上 のことから，A 型肝炎は抗体保持者が減少している可 能性があり，今後大量の発生を生じる潜在的な危険性 があるといわ的ばならず，予防的な措置や，今回の様 な流行では二次感染，三次感染を防ぐ必要がある．し かも，感染に対する対策はかなり広域にわたることが 必要である，さらに，高踹者の発症が多発する傾向に あり，高齢者では重篤化しゃすいことを考虑して慎重 に対処する必要があると考えられた。

尚この論文の要旨は第26回日本肝䁍学会西部会において 発表した。

\section{文献}

1）市田文弘：A 型肝炎研究班釉括報告. 厚生省肝炎 研究連絡協議会, 昭和 62 年度報告書, p5

2）森次保雄, 田中智之, 志方俊夫：日本に㧍ける A 型肝炎の予備調查. 肝葴 $19: 237-245,1978$

3）白地良一, 秋山和夫, 新妻沢夫：宮城県に拈ける最 近の A 型肝炎流行実態と血清疫学. 臨床とウイル ᄌ $14: 331-335,1986$

4) Taylor-Wiedeman J, Moritsugu Y, Miyamura $K$, et al: Seroepidemiology of hepatitis A virus in Japan. Jpn J Med Sci Biol 40 : 119-130, 1987 
5）神代龍吉, 佐田通夫, 鈴木 宏, 他：高年龄層の A 型肝炎の臨床的検討。肝渡 $29: 457-462,1988$

6）村岡春雄：A 型肝炎の重症化因子に関する臨床的 研究. 日消誌 $87: 1383-1391,1990$

7）市田文弘：A 型肝炎研究班総括報告。厚生省肝炎 研究連絡協議会, 昭和59年度報告書, p61

8）兵庫県西脇保健所：西脇保揵所管内における A 型肝炎発生状況調查報告書, 1990

9）谷川久一, 久保康彦, 阿部弘彦, 他：佐賀県基山町 の流行性肝炎。臨床成人病 $8: 39-45,1978$

10）奈良秀八州, 鉿木健二, 門馬 孝, 他：ある施設に 集団発生したA 型肝炎について，肝甈 19：9 $-21,1978$

11）井本正巳, 中野 哲, 綿引 元, 他：中学生に集団 発生した A 型肝炎の臨床的検討. 第 2 報、 A 型肝 炎の臨床程過を中心として。肝荿 21：1295 $-1303,1980$

12）小池通夫, 柏井洋臣, 住山景一郎, 他：1978年和歌 山県本宮町で発生した A 型肝炎流行例の臨床的, ウイルス学的および防疫面の検討. 日小誌 84 : $552-560,1980$

13）吉田 貴, 若原達男, 山田重樹, 他：家族内に多発
したA 型肝炎の臨床的検討。肝䁍 20：1084 $-1088,1979$

14）大山正巳, 清水 勝, 龟谷正明, 他：A 型肝炎の家 族内発生。日消誌 $77: 1108-1112,1980$

15）川上広育, 竹野 弘, 松浦寿二郎, 他：A 型急性肝 资の家族内発生をみた 3 家系の臨床的検討. 肝胆 膵 $7: 771-778,1983$

16）西原 隆，山田剛太郎，水野元夫，他：昭和55年の 1 月から 5 月にかけて岡山市東南部を中心に多発 した散発性 A 型肝炎の疫学的検討. 肝葴 $22: 925$ $-932,1981$

17）奈良秀八洲，相沢道郎，川部汎康，他：青森県に流 行した A 型肝资についての疫学的研究. 肝缄 25: $1377-1384,1984$

18) Fujiyama S, Akahoshi M, Sagara K, et al: An epidemic of hepatitis a rerated to ingestion of raw oysters. Gastroentrol Jpn $20: 6-13,1985$

19）千葉俊明，石川和克，山崎你藤俊一：当科に おける1983年 2 月から 5 月にかけて多発した A 型肝炎の疫学的, 臨床的検討. 岩手医誌 $39: 663$ $-674,1987$

\title{
Clinical study of hepatitis A in Touban area (southern district of Hyougo Pref.) in 1990
}

\author{
Michiko Hayakawa", Mikihiko Ueno ${ }^{11}$, Hirofumi Fukumoto ${ }^{21}$, Takeo GotoH $^{31}$, \\ Shinichi SHIMIZU ${ }^{4}$, Masahiko AMANo ${ }^{5)}$ and Tadanobu CHINZEI ${ }^{6)}$
}

From December 1989 to July 1990, we have experienced 215 cases of acute hepatitis type A in Touban area, southern district of Hyougo Prefecture. The mean age of patients was 32.7 (range 2 to 79). Fifty four patients (25\%) were in their forth decade, and the number of patients over 60 was 9 (4.2\%). The incidence revealed there were two epidemic peaks. The earlier was in March and the later was in May. The number of familial outbreaks was 32, in 14 families. But 20 patients ( 9 families) who had other patient in his residential family occurred almost same time, they were not thought to be intrafamilial infected. The biochemical data were the following. The mean total serum bilirubin was $5.2 \mathrm{mg} / \mathrm{d} l(0.4-19.9)$, GOT $1417 \mathrm{IU} / \mathrm{L}$ (41-7590), GPT $1835 \mathrm{IU} / \mathrm{L}(40-7060)$. And the serum bilirubin level was correlated with patients age, that suggests the old patients tend to be serious.

\footnotetext{
1) Kakogawa National Hospital (Hyougo)

2) Shinkou Kakogawa Hospital(Hyougo)

3) Takasago City Hospital(Hyougo)

4) Ono City Hospital(Hyougo)

5) Nishiwaki City Hospital(Hyougo)

6) Kakogawa City Hospital(Hyougo)
} 